\title{
Mapping of coconut growing areas in Tamil Nadu, India using remote sensing and GIS
}

\author{
Balaji Kannan ${ }^{*}$, K.P. Ragunath ${ }^{1}$, R. Kumaraperumal ${ }^{1}$, R. Jagadeeswaran ${ }^{1}$ and \\ R. Krishnan ${ }^{2}$ \\ ${ }^{1}$ Department of Remote Sensing and Geographic Information System, Tamil Nadu Agricultural University, \\ Coimbatore - 641003 (Tamil Nadu) INDIA \\ ${ }^{2}$ Office of the Dean (Agriculture), Tamil Nadu Agricultural University, Coimbatore - 641003 (Tamil Nadu), INDIA \\ *Corresponding author. E-mail: balajikannan@tnau.ac.in
}

Received: June 24, 2016; Revised received: November 11, 2016; Accepted: April 15, 2017

\begin{abstract}
Importance of remotely sensed data for inventorying, mapping, monitoring and for the management and development planning for the optimum utilization of natural resources has been well established. Though, a lot of applications have been attempted using remote sensing tool, mapping of coconut growing areas has not been attempted at a regional level. Hence, this study was envisaged to map the coconut growing areas in Tamil Nadu, India using Survey of India Toposheet grid (1:50,000 scale) and Digital Globe data. The temporal window of these datasets ranged from March 2012 to June 2014. The data sets have a spatial resolution of $41 \mathrm{~cm}$. It has been observed that Coimbatore has largest area under coconut among all districts of Tamil Nadu, followed by Tiruppur, Thanjavur and Dindigul. In terms of percentage of coconut area to the total geographical area of the district, Tiruppur, leads the list, followed by Kanya kumari, Coimbatore and Thanjavur. On comparing the area obtained by this study with the area as per Coconut Development Board using a paired t-test, a p-value of 0.005 was obtained and hence, there is no significant difference between the two. Hence, it can be said that geospatial technologies like remote sensing and geographical information system are the best tools for accurate assessment and spatial data creation for crop mapping and area assessment.
\end{abstract}

Keywords: Area mapping, Coconut, Geographical information system, Remote sensing, Spatial data

\section{INTRODUCTION}

Coconut is grown in more than 80 countries. Tree crop such as coconut is of major importance to India's economy. The coconut tree has an unfathomed influence on the rural economy and it provides livelihood to more than 10 million people. The contribution of coconut oil to the national edible oil pool is $6 \%$. In addition, the crop contributes Rs. 7000 crores annually to the Gross Domestic Product (GDP) (Theerkhapathy and Chandrakumarmangalam, 2014). Hence, the cultivation of coconut is spreading to non-traditional areas. The coconut-palm adapts itself remarkably well and thrives in almost all types of well-drained tropical soils, such as laterite, alluvial, red sandy loam, coastal sandy and reclaimed soils with a $\mathrm{pH}$ ranging from 5.2 to 8.0. But the palm does show certain growth preferences to soil types. A variety of factors such as drainage, soil depth, soil fertility and layout of the land has great influence on the growth of the palm. The depth of rooting depends much on the physical characteristics of the soil and the depth of the water table (Anonymous, 2013).

The complexity of the data requirement for decisionmaking and planning for management of coconut eco- system makes the conventional method of collecting data rather difficult. More over collection of information through hierarchy of aggregation of farm, village, block, district, state and national level create undue delay and approximation of information. Importance of remotely sensed data for inventorying, mapping, monitoring and for the management and development planning for the optimum utilization of natural resources has been well established. The use of satellite based remote sensing technique has proved itself as a strong and unbiased information system at regular intervals of time. Remote sensing techniques have been operationally used in many countries to provide basic information on crops, soils, water resources and the impact of drought and flood on agriculture.

Palaniswami et al. (2006) undertook a study to test the stability of a spectral mixture modeling method by applying the model to produce land-cover maps of coconut in Kasaragod district, Kerala. Classification results from applying the Spectral Mixture Analysis (SMA) were assessed by comparison with ground-truth data. The subpixel accuracy achieved for the coconut land-cover was $87 \%$ using SMA of DN values, while it was $93 \%$ for SMA of radiance values. 


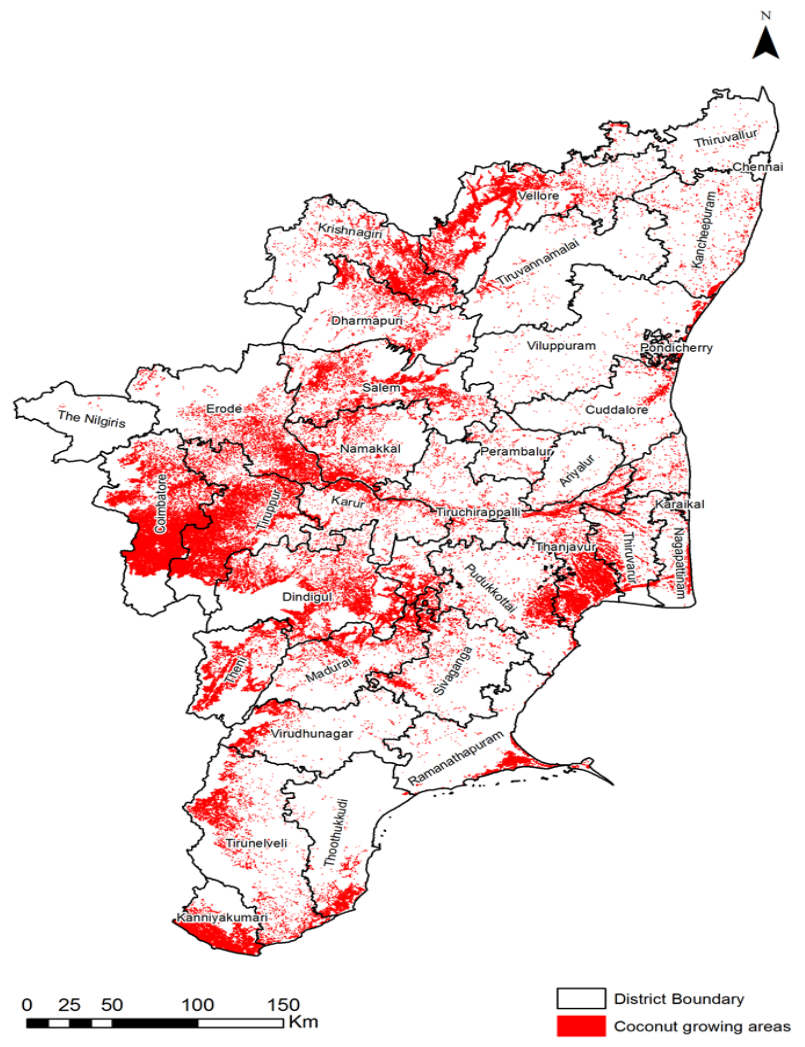

Fig. 1. Coconut growing areas in Tamil Nadu, India mapped through remote sensing and GIS.

Spatial resolution offered by sensors, such as IKONOS, Geo Eye and Quick Bird, differences between sunlit leaves, bark and shade become prominent, making it difficult to delineate tree crowns (Nagendra and Rocchini, 2008). Under such circumstances, traditional, pixel-based classification of tree canopies becomes challenging, due to the high contrast between pixels that represent different parts of a single object (Wang et al., 2010). World view 2 imagery with its rich spatial and spectral information content has very high potential for discrimination of the less varied varieties of vegetation (Kumar and Roy, 2013). Spatial information on coconut cultivation such as acreage, soil type in which it is grown are lacking and which will be of very much use for developing site/soil specific management strategies to augment the production of coconut in the existing area and also in non-traditional areas. Hence, this research study was attempted to create a spatial data base on coconut acreage under different soil types over the coconut growing districts of Tamil Nadu.

\section{MATERIALS AND METHODS}

Study area and data used: The study was done for the State of Tamil Nadu, India. The Geo Eye data were used for digitizing coconut area using the Professional Licensed Google Earth browser. The temporal window of these datasets ranged from March 2012 to
Table 1. District wise area of coconut in Tamil Nadu, India.

\begin{tabular}{|c|c|c|}
\hline District & $\begin{array}{c}\text { Area as per } \\
\text { this study } \\
\text { (ha) }\end{array}$ & $\begin{array}{l}\text { Area as per Coconut } \\
\text { Development Board } \\
(2012-13) \text { in ha }\end{array}$ \\
\hline Ariyalur & 223 & 341 \\
\hline Coimbatore & 84,653 & 83,341 \\
\hline Cuddalore & 1,925 & 1,990 \\
\hline Dharmapuri & 7,715 & 7,085 \\
\hline Dindigul & 31,507 & 29,932 \\
\hline Erode & 14,472 & 12,623 \\
\hline Kancheepuram & 2,635 & 3,358 \\
\hline Kanniyakumari & 24,324 & 24,502 \\
\hline Karur & 7,492 & 6,312 \\
\hline Krishnagiri & 17,209 & 15,834 \\
\hline Madurai & 11,382 & 11,221 \\
\hline Nagapattinam & 3,241 & 3,665 \\
\hline Namakkal & 9,070 & 7,460 \\
\hline Perambalur & 523 & 568 \\
\hline Pudukkottai & 9,046 & 8,716 \\
\hline Ramanathapuram & 7,159 & 8,427 \\
\hline Salem & 16,584 & 14,476 \\
\hline Sivaganga & 7,413 & 6,683 \\
\hline Thanjavur & 35,168 & 34,747 \\
\hline The Nilgiris & 53 & 64 \\
\hline Theni & 21,207 & 19,967 \\
\hline Thiruvallur & 710 & 6,574 \\
\hline Thiruvarur & 5,135 & 1,077 \\
\hline Thoothukkudi & 6,338 & 688 \\
\hline Tiruchirappalli & 7,089 & 4,805 \\
\hline Tirunelveli & 15,701 & 5,834 \\
\hline Tiruppur & 58,550 & 15,806 \\
\hline Tiruvannamalai & 1,162 & 53,661 \\
\hline Vellore & 27,974 & 22,720 \\
\hline Viluppuram & 1,915 & 1,807 \\
\hline Virudhunagar & 9,892 & 9,837 \\
\hline
\end{tabular}

Source: Anonymous (2016). The result of paired t-test has shown that, the $\mathrm{p}$ value is found to be 0.005 , and hence there was no significant difference between the area obtained from this study and the area as per Coconut Development Board (2012-13)

June 2014. The spatial resolution of the dataset is $41 \mathrm{~cm}$.

Methodology: The base layers used for this project were the digital map of district boundaries for Tamil Nadu and Survey of India Toposheet grids (1:50,000 scale) were used to guide the digitization work in a systematic manner so as to ensure complete coverage of entire State of Tamil Nadu.

The remote sensing data were visually interpreted and the boundaries of each contiguous region of coconut area were digitized onscreen. The digitization was guided by the grid of 1:50000 scale Topomaps of Survey of India. This ensured that no area is left out from searching for coconut crop. This also helped in organizing mutiseat digitization of coconut area.

The quality of the coconut area digitization was ensured by ground truth collection in a systematic manner. After completing digitization in 10 to 15 topomap grids, the digitized coconut area boundaries were 
exported to ArcGIS. The polygons were checked for topology and corrected if necessary. Random sample points for ground truth verification were generated and sufficient numbers of points were retained for verification based on the accessibility. These locations were physically checked using GPS guidance for traversing. The possible conditions namely, the area being coconut on the ground and not digitized in the map (omission error) as well as other fruit tree orchards those were mapped as coconut (commission error) were carefully examined during ground truth activity. The error in digitizing coconut area was negligible as the visual hues of tree crown and planting pattern present in the datasets used were typical for coconut plantations.

\section{RESULTS AND DISCUSSION}

Coconut growing areas were classified / identified using the methodology as mentioned in the previous section. The coconut growing areas obtained in the form of map was then used for estimating the area. Since the data is in spatial form, area calculation for each district of Tamil Nadu was generated. Table 1 shows the district wise area of coconut in Tamil Nadu, India. It was observed that Coimbatore has largest area under coconut among all districts of Tamil Nadu, followed by Tiruppur, Thanjavur and Dindigul. In terms of percentage of coconut area to the total geographical area of the district, Tiruppur, leads the list, followed by Kanyakumari, Coimbatore and Thanjavur. A comparison between area obtained from this study and the area statistics released by Coconut Development Board (Anonymous, 2016) was done using paired t-test and the p-value was 0.005 , which indicates that there is no significant difference between the two data.

The results showed that the mapping of coconut growing areas can be successfully done using remote sensing. The study is in conjunction with the study conducted by Agarwal et al. (2013) who assessed the potential of multi-spectral Geo Eye imagery for biodiversity assessment in an urban context in Bangalore, India. Six most common tree species including Cocus nucifera, collectively representing $43 \%$ of the total trees sampled, were selected for mapping using pixelbased approach. All pairs of species were separable based on spectral reflectance values in at least one band.

\section{Conclusion}

This study has proven that geospatial technologies like remote sensing and geographical information system are the best tools for accurate assessment and spatial data creation for crop mapping and area assessment.

\section{ACKNOWLEDGEMENTS}

The author sincerely acknowledges the financial sponsor of this study, Coconut Development Board, Kochi, Kerala, India. The author also sincerely acknowledges Coconut Research Station, Aliyar Nagar, Coimbatore, Tamil Nadu, India and Coconut Research Station, Veppankulam, Thanjavur, Tamil Nadu, India for their technical guidance.

\section{REFERENCES}

Anonymous (2013). Crop production techniques of Horticultural crops. Tamil Nadu Agricultural University, Coimbatore Pp. 197, India

Anonymous (2016). Horticulture Division, Dept. of Agriculture and Cooperation, Ministry of Agriculture and Farmers Welfare, Government of India

Kumar, M. and Roy, P. S. (2013). Utilizing the potential of World View -2 for discriminating urban and vegetation features using object based classification techniques. $J$ Indian Soc Remote Sens.

Nagendra, H. and Rocchini, D. (2008). High resolution satellite imagery for tropical biodiversity studies: The devil is in the detail. Biodivers. Conserv., 17:3431-3442

Palaniswami, C., Upadhyay, A. K. and Maheswarappa, P. (2006). Spectral mixture analysis for subpixel classification of coconut. Current Science, 91:12-25

Agarwal, S., Lionel Sujay Vailshery, Madhumitha Jaganmohan and Harini Nagendra (2013). Mapping urban tree species using very high resolution satellite imagery: comparing pixel-based and object-based approaches. ISPRS Int. J. Geo-Inf., 2:220-236

Theerkhapathy, S.S. and S. Chandrakumarmangalam (2014). Coconut Processing Industries: An Outlook. Global Journal of Commerce and Management Perspective, 3 (5):219-221

Wang, K., Franklin, E. S., Guo, X. and Cattet, M. (2010). Remote sensing of ecology, biodiversity and conservation: A review from the perspective of remote sensing specialists. Sensors, 10: 9647-9667 